\title{
Effects of Lime-Aluminium-Phosphate Interactions on Maize Growth and Yields in Acid Soils of the Kenya Highlands
}

\author{
Esther Mwende Muindi ${ }^{1, *}$, Jerome Mrema ${ }^{2}$, Ernest Semu ${ }^{2}$, Peter Mtakwa ${ }^{2}$, Charles Gachene \\ ${ }^{1}$ Department of Crop Science, Pwani University, Kilifi, Kenya \\ ${ }^{2}$ Department of Soil Science, Sokoine University of Agriculture, Morogoro, Tanzania \\ ${ }^{3}$ Department of Land Resource Management, University of Nairobi, Nairobi, Kenya
}

Email address:

e.muindi@pu.ac.ke (E. M. Muindi)

\section{To cite this article:}

Esther Mwende Muindi, Jerome Mrema, Ernest Semu, Peter Mtakwa, Charles Gachene. Effects of Lime-Aluminium-Phosphate Interactions on Maize Growth and Yields in Acid Soils of the Kenya Highlands. American Journal of Agriculture and Forestry.

Vol. 3, No. 6, 2015, pp. 244-252. doi: 10.11648/j.ajaf.20150306.11

\begin{abstract}
Soil acidity and phosphorus (P) deficiency are some of the major causes of low maize yields in Kenya. Although considerable work has been done to establish liming rates for acid soils in many parts of the world, information on the effects of the lime-Al-P interactions on maize growth and yield is limiting. A green house pot experiment was conducted at Waruhiu Farmers Training Centre, Githunguri to evaluate the effects of lime-Al-P interactions on maize growth and yield in acid soils of the Kenya highlands. Extremely acidic (pH 4.48) and strongly acidic ( $\mathrm{pH} 4.59)$ soils were used for the study. Four lime (CaO) rates and phosphorus $\left(\mathrm{Ca}\left(\mathrm{H}_{2} \mathrm{PO}_{4}\right)_{2}\right.$ rates were used. The liming rates were: $0,2.2,5.2$ and 7.4 tonnes ha ${ }^{-1}$ for extremely acidic soil and $0,1.4,3.2$, and 4.5 tonnes ha ${ }^{-1}$ for the strongly acidic soil. Phosphorus applications rates were: $0,0.15,0.30$ and $0.59 \mathrm{mg} \mathrm{P}$ $\mathrm{kg}^{-1}$ soil for the extremely acidic soil and $0,0.13,0.26$, and $0.51 \mathrm{mg} \mathrm{P} \mathrm{kg}^{-1}$ for strongly acidic soil. The experiments were a $4^{2}$ factorial laid down in a Randomized Complete Block Design (RCBD) and replicated three times. Data collected included: plant height, number of leaves, P-uptake and maize dry matter yield. Lime-Al-P interaction significantly $(\mathrm{P} \leq 0.05)$ increased $\mathrm{P}$ concentrations in maize tissues, maize height, dry matter yields. Use of 7.4 tonnes $\mathrm{ha}^{-1}$ in extremely acidic soils and 4.5 tonnes $\mathrm{ha}^{-1}$ in strongly acidic soils significantly $(\mathrm{P} \leq 0.05)$ increased maize height compared to lower lime rates. Phosphorus uptake and dry matter yields did not however, vary when 7.4 tonnes $\mathrm{ha}^{-1}$ lime was combined with either $0.59 \mathrm{mg} \mathrm{P} \mathrm{kg}^{-1}$ or $0.3 \mathrm{mg} \mathrm{P} \mathrm{kg}^{-1}$ in extremely acidic soils, and 4.5 tonnes $\mathrm{ha}^{-1}$ was combined with either $0.51 \mathrm{mg} \mathrm{Pg} \mathrm{k}^{-1}$ or $0.26 \mathrm{mg} \mathrm{kg} \mathrm{k}^{-1}$ in strongly acidic soils. It was, therefore, concluded that lime and P positively interact to reduce Aluminium toxicity in the soils and improve maize growth, $\mathrm{P}$ uptake and yields in acid soils in the Kenya highlands. However, further research is required to evaluate long term effects of the interactions on crop yields, uptake of plant nutrients under field conditions.
\end{abstract}

Keywords: Lime, Phosphorus, Aluminium, Acid Soils, Maize Yields, P-uptake

\section{Introduction}

In highly weathered, acid soils around the world, $\mathrm{P}, \mathrm{Ca}$, and $\mathrm{Mg}$ deficiencies and aluminum (Al) and manganese $(\mathrm{Mn})$ toxicities are the most important nutritional and/or element disorders that limit crop yields $[1,2]$. Phosphorus deficiency in such soils is attributed to adsorption of $\mathrm{P}$ by $\mathrm{Al} / \mathrm{Fe}$ oxides and hydroxides, such as gibbsite, hematite, and goethite [3]. The phosphorus is first adsorbed on the surface of clay minerals and $\mathrm{Fe}$ or $\mathrm{Al}$ oxides by forming various complexes. Non protonated and protonated bidentate surface complexes may coexist at $\mathrm{pH} 4$ to 9 , while the protonated bidentate inner sphere complex is predominant under acidic soil conditions [4, 5]. Phosphorus may also be occluded in nanopores that frequently occur in $\mathrm{Fe} / \mathrm{Al}$ oxides, and thereby become unavailable to plants [5].

Aluminium toxicity is a major growth limiting factor for crop production in acid soils [6]. It impedes both cell elongation and cell division leading to reduced root growth [7, 8] hence reduced ability of the plant to explore the soil volume for nutrients and water leading to nutrient and water stress. Aluminium toxicity can also interfere with active ion uptake processes across the root-cell plasma membrane [7]. 
Liming modifies the physical, chemical and biological characteristics of soil through its direct effect on amelioration of soil acidity $[9,10,11]$. It also plays an indirect role of mobilization of plant nutrients, immobilization of toxic heavy metals and improvement of soil structure [12]. Physical amelioration of lime occurs through flocculation of colloid particles which leads to changes in surface potential and charge densities [13] while chemical amelioration of lime occurs through increased $\mathrm{Ca}^{2+}$ and /or $\mathrm{Mg}^{2+}$ ions in the soil solution and increased soil $\mathrm{pH}$, thereby reducing the activities / concentrations of $\mathrm{Al}^{3+}$ and $\mathrm{Fe}^{3+}, \mathrm{H}^{+}, \mathrm{Mn}^{4+}$ and $\mathrm{Fe}^{3+}$ ions in the soil solution. Liming also improves microbiological activities of acid soils, which in turn can increase dinitrogen fixation by legumes and liberate nitrogen $(\mathrm{N})$ from incorporated organic materials.

Although liming of acid soils has been shown to have a variable effect on $\mathrm{P}$ sorption capacity, increased sorption on limed soils is attributed to formation of active $\mathrm{x}$-ray amorphous Al hydroxyl polymers, which actively sorb more $\mathrm{P}$ than $\mathrm{Al}^{3+}[14]$. The active $\mathrm{Al}$ hydroxyl polymers formed can also coat the surfaces of minerals, thereby affecting their surface charge characteristics [15] and P sorption of the soils.

Liming an acid soil to above about $\mathrm{pH} 5.5$ has also been reported to increase plant growth [16]. This positive growth response to lime has been attributed to amelioration of Al-toxicity and / increased P availability [17, 18]. However, high rates of lime, which increase the $\mathrm{pH}$ values above 6.5, have been reported to depress plant growth [16, 19]. The decrease in yields have been attributed by [16] to three possible reasons, namely, reduction of infiltration due to formation of smaller soil aggregates, micronutrient deficiencies at higher $\mathrm{pH}$ and induced $\mathrm{P}$ deficiency due to formation of insoluble calcium phosphate (Ca-P) compounds. However, [20] attributed the yield decrease to $\mathrm{Al}$ reactions in the soil where the level of exchangeable $\mathrm{Al}$ at a given $\mathrm{pH}$ reflected the reactivity of the aluminium surfaces which, in turn, governed the solubility of $\mathrm{P}$.
Kenyan soils, similar to other agricultural soils of the tropics, have low available $\mathrm{P}$, high $\mathrm{Al}$ concentrations and high P-fixation capacities [21, 22, 23] attributable to extensive weathering and dominance of $\mathrm{Al}, \mathrm{Fe}$, and $\mathrm{Mn}$ oxyhydroxides and 1:1 layer silicates and extensive leaching of the basic cations and high concentration of $\mathrm{Al}^{3+}$ and $\mathrm{Fe}^{3+}$ in the soil solution and on the cation retention sites and the soil colloids. Under these situations, an appropriate combination of lime and $\mathrm{P}$ is an important strategy for improving field crops yield in highly weathered soils. Several workers have tested and documented the effect of liming on nutrient availability in acid soils of the western highlands of Kenya [22, 24, 25]. However, information on the interaction of lime, $\mathrm{Al}$ and $\mathrm{P}$ to ensure optimal availability of $\mathrm{P}$ as assessed by plant uptake in Kenya highlands soils is limiting. The objective of this study was, therefore, to evaluate the effects of lime-Al-P interaction on $\mathrm{P}$ uptake, maize growth and yield.

\section{Materials and Methods}

\subsection{Experimental Layout, Design and Crop Husbandry}

A greenhouse pot experiment was carried out at Waruhiu Farmers' Training Centre, Githunguri, Kiambu County. Two composite soil samples representing extremely acid $(\mathrm{pH}$ 4.0-4.5) and strongly acidic ( $\mathrm{pH} 5.0-5.5)$ soils, as described by [9] were used in the study. The experiments were a $4^{2}$ factorial laid down in a Randomized Complete Block Design (RCBD) and replicated three times. The treatments were lime application rates and phosphorus application rates. Liming rates were chosen to obtain $0,30,70$ or $100 \%$ reduction in amounts of $\mathrm{M} \mathrm{KCl-extractable} \mathrm{Al}$ originally present in the soil while the phosphorus levels added were: $0,0.5,1$ or 2 times the standard phosphorus requirement (SPR) of the tested soils (Table 1). Burnt lime $(\mathrm{CaO})$ containing about $21 \%$ calcium oxide was used in this study while triple superphosphate fertilizer $\left[\mathrm{Ca}\left(\mathrm{H}_{2} \mathrm{PO}_{4}\right)_{2}\right]$ as used as $\mathrm{P}$ - source.

Table 1. Actual amounts of phosphorus and lime added in the acid soils.

\begin{tabular}{lllllllll}
\hline & \multicolumn{3}{l}{ Lime added (tones ha $\mathbf{~ h}^{-1}$ ) } & \multicolumn{5}{c}{ P added (g P $\mathbf{~ g g}^{-1}$ soil) } \\
\hline Soil & $0 \%$ & $30 \%$ & $70 \%$ & $100 \%$ & 0 SPR & 0.5 SPR & 1 SPR & 2 SPR \\
Extremely Acidic & 0 & 2.2 & 5.2 & 7.4 & 0 & 0.15 & 0.30 & 0.59 \\
Strongly Acidic & 0 & 1.4 & 3.2 & 4.5 & 0 & 0.13 & 0.26 & 0.51 \\
\hline
\end{tabular}

SPR-Standard phosphate requirement

Five kilogramme composite soil samples for both extremely and strongly acid soils were measured and put in nine litre plastic pots. The different lime levels were measured and incorporated into the soil samples by thoroughly mixing and incubating at field capacity for a period of 21 days. Water was added every 2 days to compensate for evaporative losses and the soils were remixed thoroughly. After incubation, soils from each liming level were air-dried, sieved and returned to the plastic pots. Various P levels were then added and the soils re- incubated at the same conditions for 14 days after which they were air dried and used for plant growth studies.

A plant growth study was conducted in a greenhouse. Lime-P treated soils $(4 \mathrm{~kg})$ were mixed with Calcium
Ammonium Nitrate (CAN) at the rate of $50 \mathrm{~kg} \mathrm{~N} \mathrm{ha}^{-1}$ then placed in plastic containers with the container lids placed underneath to obtain any leachate. Each treatment was replicated three times. The potted soils were moistened to field capacity with water and three maize seeds planted in each pot. Nduma maize variety was used. After 14 days, the plants were thinned to one plant per pot.

\subsection{Laboratory Analysis}

Soil physiochemical analysis and $\mathrm{P}$ adsorption were determined before application of treatments. Soil $\mathrm{pH}$, exchangeable aluminum, $\mathrm{CEC}$, and particle size distribution 
were analyzed as described by [26]. Extractable P was determined by dry ashing techniques as described by [27] while phosphorus sorption capacities of the soils were evaluated as described by [28] and the $\mathrm{P}$ adsorbed data for the two soils fitted into the linearized form of the Langmuir equation. The lime requirements of the soils were calculated using the equation of [29]. The equation aims at reducing the $\%$ $\mathrm{Al}$ saturation to a level that is commensurate with crop $\mathrm{Al}$ tolerance, and is given as: Lime required $\left(\mathrm{CaCO}_{3}\right.$ equiv. $)$ tones $\mathrm{ha}^{-1}=1.8[\mathrm{Al}-\mathrm{RAS}(\mathrm{Al}+\mathrm{Ca}+\mathrm{Mg}) / 100]$ where $\mathrm{Al}=\mathrm{cmol}$ $\mathrm{kg}^{-1}$ soil in the original exchange complex, RAS $=$ Required percentage $\mathrm{Al}$ saturation, $\mathrm{Ca}=\mathrm{cmol} \mathrm{kg}^{-1}$ soil in the original exchange complex, $\mathrm{Mg}=\mathrm{cmol} \mathrm{\textrm {kg } ^ { - 1 }}$ soil in the original exchange complex. A RAS value of $20 \%$ was used. Soil characterization data in Table 2 below was used for lime requirement determinations.

\subsection{Crop Growth Data Collection}

Crop growth data collected included: plant height, number of leaves, and dry matter yield. Maize height and number of leaves were measured weekly from crop emergence until 35 days after emergence. Thirty five days after germination, the maize plants were cut and the above ground parts weighed, then oven dried at $70^{\circ} \mathrm{C}$ up to constant weights. Soil from each pot was also thoroughly mixed and subsamples taken to the soil science laboratory at the University of Nairobi for physical and chemical analysis.

\subsection{Statistical Analysis}

Data obtained were subjected to Analysis of Variance (ANOVA) using the GenStat statistical package [30] and treatment effects were tested for significance using the F-test at $5 \%$ level of significance. Means were ranked using Duncan's New Multiple Range Test. Dependency tests were also conducted to find out if there was a relationship between the various variables used.

\section{Results}

\subsection{Initial Soil Physical and Chemical Characteristics}

The tested soils were acidic with $\mathrm{pH}<5.5$ (Table 2). Exchangeable Aluminium levels for both soils were $>2 \mathrm{cmol} \mathrm{kg}^{-1}$ and $\%$ Aluminium saturation $>20 \%$. Extractable was low while $\mathrm{CEC}$ was $<15 \mathrm{cmol} \mathrm{kg}^{-1}$ soil. The tested soils had clay texture.

Table 2. Physiochemical properties of the two soils before pot experiment.

\begin{tabular}{lll}
\hline & Extremely acidic & Strongly acidic \\
\hline $\mathrm{pH}$ & 4.48 & 4.59 \\
$\mathrm{Exch} . \mathrm{Al}\left(\mathrm{cmol} \mathrm{kg}^{-1}\right)$ & 3.85 & 3.90 \\
$\mathrm{OC}(\%)$ & 1.75 & 1.83 \\
$\mathrm{P}\left(\mathrm{mg} \mathrm{kg}{ }^{-1}\right)$ & 10.50 & 13.50 \\
$\mathrm{CEC}$ & 10.82 & 11.68 \\
$\mathrm{Al}$ Saturation $(\%)$ & 55.82 & 49.66 \\
\%Clay & 56.32 & 50.00 \\
\% Silt & 21.00 & 17.00 \\
\% Sand & 22.68 & 33.00 \\
Textural class & Clay & Clay \\
\hline
\end{tabular}

\subsection{The Effect of Lime-Al-P Interaction on Growth of Maize}

The effect of lime-Al-P interaction on maize height varied with levels of $\mathrm{P}$ and lime used (Table 3 ). Lime rates resulting into $100 \%$ reduction in $\mathrm{AL}^{3+}$ in the soils were observed to significantly $(\mathrm{P} \leq 0.05)$ promote the highest maize plant heights in both extremely and strongly acidic soils.

Table 3. Effect of lime-Al-P interactions on maize height (cm) in acid soils of the Kenya Highlands (averaged over 5 sampling period).

\begin{tabular}{|c|c|c|c|c|c|c|c|c|}
\hline \multirow[b]{3}{*}{ Lime to give } & \multicolumn{8}{|c|}{ Phosphorus levels applied (mg $\left.\mathrm{P} \mathrm{kg}^{-1}\right)$} \\
\hline & \multicolumn{4}{|c|}{ Extremely acidic soils } & \multicolumn{4}{|c|}{ Strongly acidic soils } \\
\hline & 0 & 0.15 & 0.3 & 0.59 & 0 & 0.13 & 0.26 & 0.51 \\
\hline $0 \%$ reduction in $\mathrm{Al}^{3+}$ & $91.7 \mathrm{a}$ & $108.0 \mathrm{a}$ & $113.0 \mathrm{a}$ & $116.0 \mathrm{a}$ & $89.7 \mathrm{a}$ & $102.0 \mathrm{a}$ & $108.7 \mathrm{a}$ & $103.8 \mathrm{a}$ \\
\hline $30 \%$ reduction in $\mathrm{Al}^{3+}$ & $97.8 \mathrm{a}$ & $118.3 \mathrm{a}$ & $123.5 \mathrm{a}$ & $132.2 \mathrm{~b}$ & $97.0 \mathrm{a}$ & $110.0 \mathrm{~b}$ & $114.6 \mathrm{a}$ & $121.4 \mathrm{~b}$ \\
\hline $70 \%$ reduction in $\mathrm{Al}^{3+}$ & $103.7 \mathrm{a}$ & $138.3 b$ & $136.0 \mathrm{~b}$ & $132.2 b$ & $102.3 \mathrm{a}$ & $118.0 \mathrm{~b}$ & $121.0 \mathrm{~b}$ & $122.0 \mathrm{~b}$ \\
\hline $100 \%$ reduction in $\mathrm{Al}^{3+}$ & $115.6 \mathrm{~b}$ & $152.9 \mathrm{c}$ & $207.2 \mathrm{c}$ & $158.2 \mathrm{c}$ & $112.9 \mathrm{~b}$ & $129.7 \mathrm{c}$ & $131.3 \mathrm{c}$ & $132.0 \mathrm{c}$ \\
\hline$\% \mathrm{CV}$ & 3.2 & 3.2 & 3.2 & 3.2 & 2.0 & 2.0 & 2.0 & 2.0 \\
\hline
\end{tabular}

Values followed by the same letter(s) on the same column are not significantly different at $\mathrm{P} \leq 0.05$.

Phosphorus use was observed to significantly $(\mathrm{P} \leq 0.05)$ increase the number of leaves per maize plant in the acid soils (Table 4). Use of $0.3 \mathrm{mg} \mathrm{P} \mathrm{kg}^{-1}$ gave the highest number of leaves in extremely acidic soils while $0.26 \mathrm{mg} \mathrm{Pg}^{-1}$ gave the highest plant height in strongly acidic soils.

Table 4. Effect of lime-Al-P interactions on number of leaves per maize plant in acid soils of the Kenya Highlands (averaged over 5 sampling period).

\begin{tabular}{|c|c|c|c|c|c|c|c|c|}
\hline \multirow[b]{3}{*}{ Lime to give } & \multicolumn{8}{|c|}{ Phosphorus levels applied (mg P kg $\left.{ }^{-1}\right)$} \\
\hline & \multicolumn{4}{|c|}{ Extremely acidic soils } & \multicolumn{4}{|c|}{ Strongly acidic soils } \\
\hline & 0 & 0.15 & 0.3 & 0.59 & 0 & 0.13 & 0.26 & 0.51 \\
\hline $0 \%$ reduction in $\mathrm{Al}^{3+}$ & $21.0 \mathrm{a}$ & $26.7 b$ & $29.3 c$ & $26.3 b$ & $20.7 \mathrm{a}$ & $21.3 \mathrm{a}$ & $26.3 b$ & $23.7 \mathrm{c}$ \\
\hline $30 \%$ reduction in $\mathrm{Al}^{3+}$ & $22.0 \mathrm{a}$ & $27.7 \mathrm{~b}$ & $30.3 \mathrm{c}$ & $27.7 b$ & $21.3 \mathrm{a}$ & $24.0 \mathrm{~b}$ & $27.0 \mathrm{c}$ & $24.3 b$ \\
\hline $70 \%$ reduction in $\mathrm{Al}^{3+}$ & $22.7 \mathrm{a}$ & $27.7 \mathrm{~b}$ & $31.0 \mathrm{c}$ & $27.7 b$ & $21.7 \mathrm{a}$ & $24.0 \mathrm{~b}$ & $28.7 \mathrm{c}$ & $24.3 b$ \\
\hline $100 \%$ reduction in $\mathrm{Al}^{3+}$ & $23.0 \mathrm{a}$ & $27.7 \mathrm{~b}$ & $31.0 \mathrm{c}$ & $28.7 b$ & $22.7 \mathrm{a}$ & $27.3 \mathrm{a}$ & $31.7 \mathrm{~b}$ & $27.0 \mathrm{~b}$ \\
\hline$\% \mathrm{CV}$ & 3.7 & 3.7 & 3.7 & 3.7 & 4.7 & 4.7 & 4.7 & 4.7 \\
\hline
\end{tabular}

Values followed by the same letter(s) within a row are not significantly different at $\mathrm{P} \leq 0.05$. 
Average height of maize plants growing under different lime rates in the extremely acidic soils was not significantly different until the $4^{\text {th }}$ week after germination (Figure 1). On the other side, the heights of the maize plants in strongly acidic soils were significantly different from the $3^{\text {rd }}$ week after emergence (Figure 2).

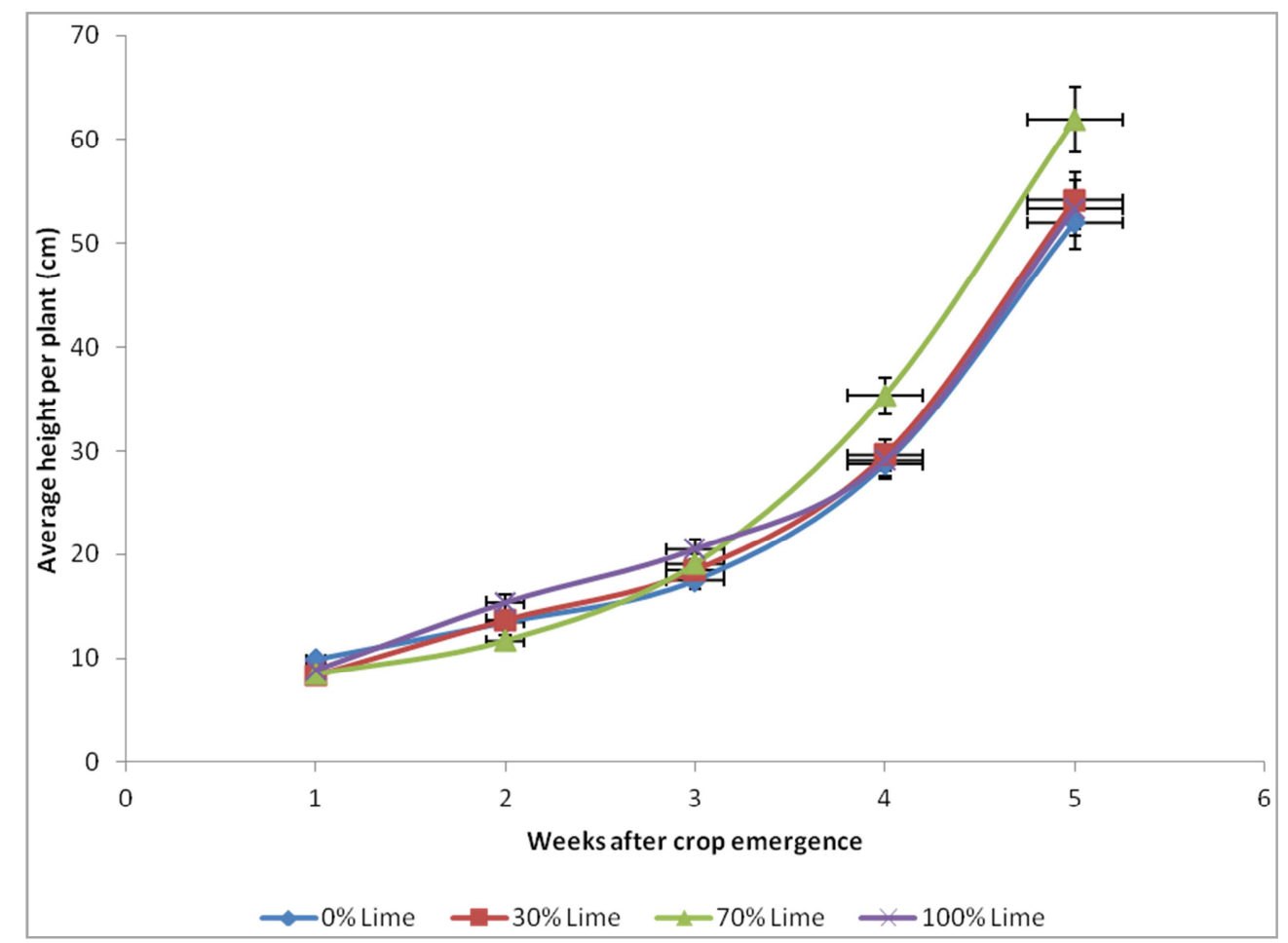

Figure 1. Effects of liming on heights of maize plants planted in extremely acidic soils (LSD bars inserted).

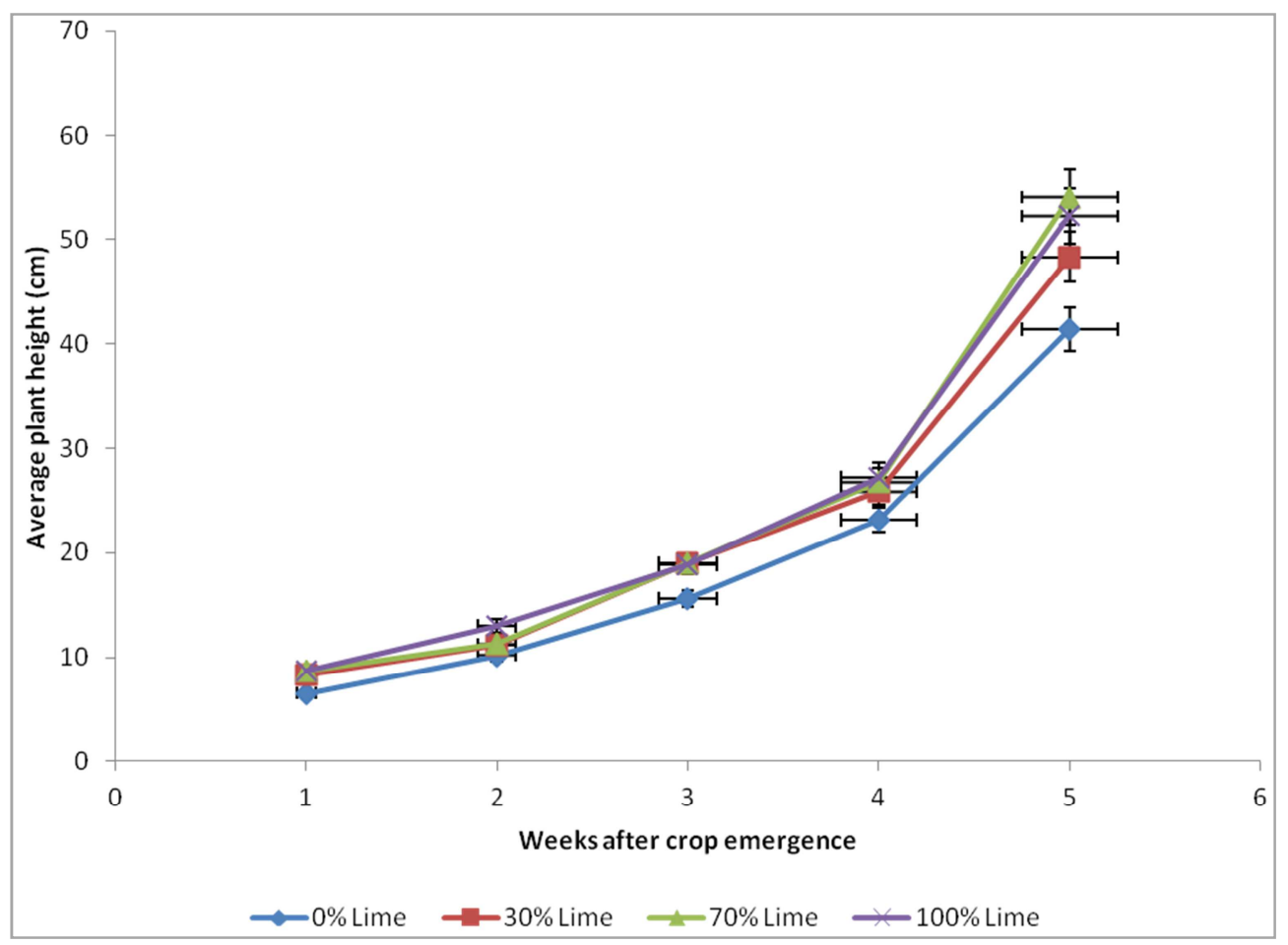

Figure 2. Effects of liming on heights of maize plants planted in strongly acidic soils (LSD bars inserted).

Average numbers of leaves from maize plants grown under different lime rates in extremely acidic soils were significantly different from the $4^{\text {th }}$ week after emergence (Figure 3 ). On the contrally, number of leaves from plants grown in strongly acidic soils were significantly different from $2^{\text {nd }}$ week after emergence (Figure 4). 


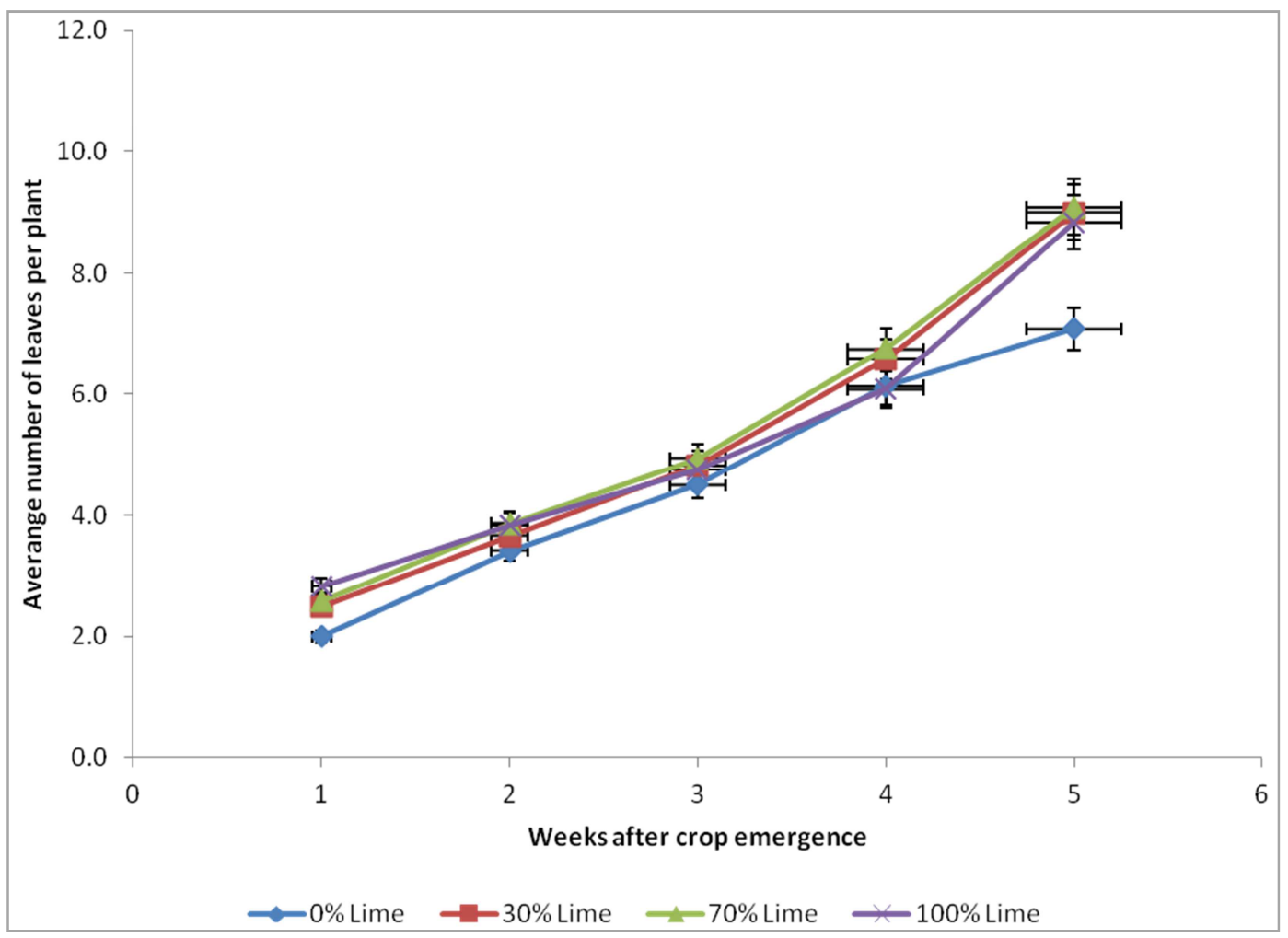

Figure 3. Effects of liming on number of leaves from maize planted in extremely acidic soils (LSD bars inserted).

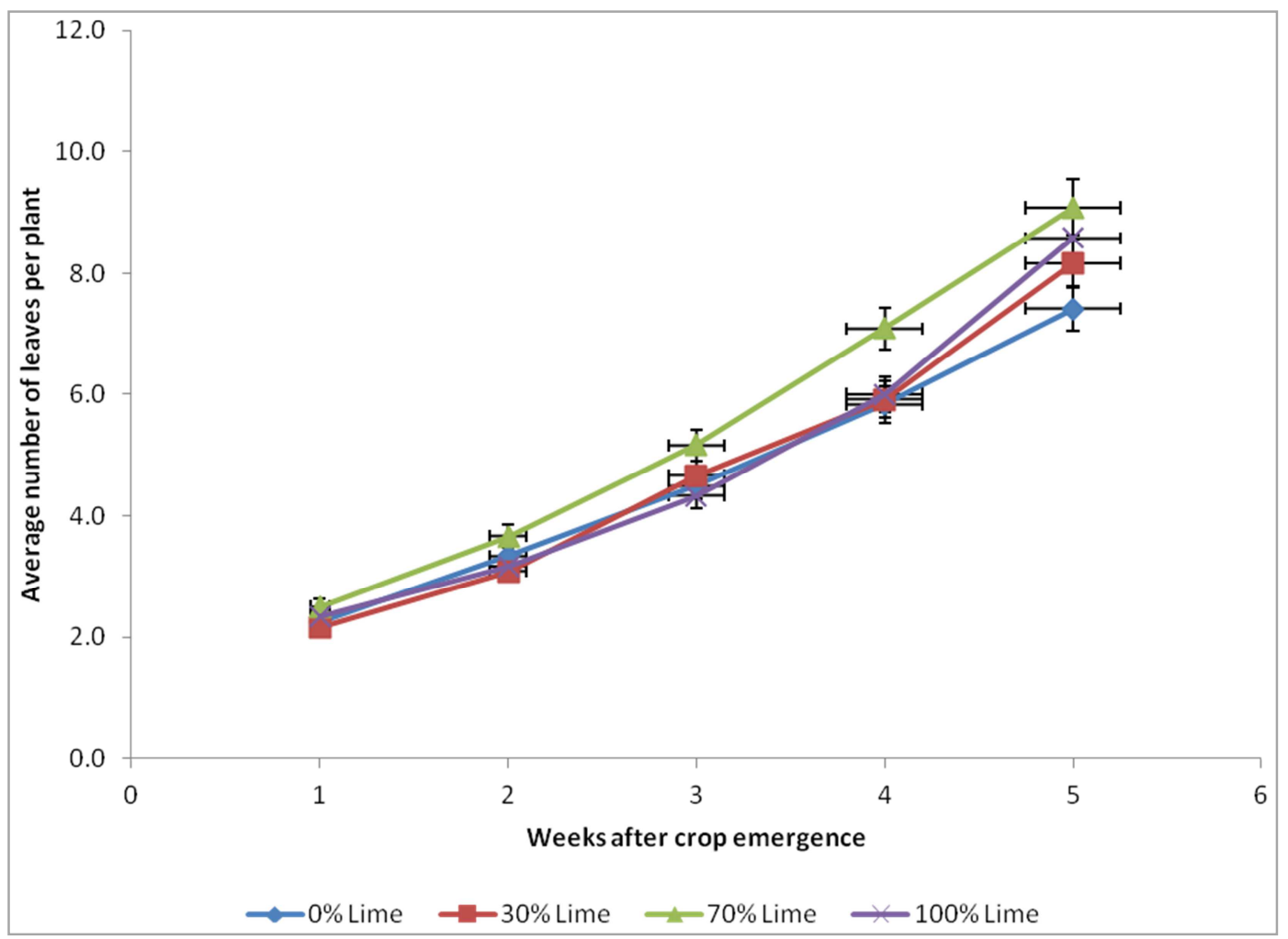

Figure 4. Effects of liming on maize plant leaves in strongly acidic soils (LSD bars inserted).

Maize leaf area index was significantly different from $3^{\text {rd }}$ week after emergence under different lime rates in extremely acid soils (Figure 5). Similar trends were observed in strogly acid soils (Figure 6). 


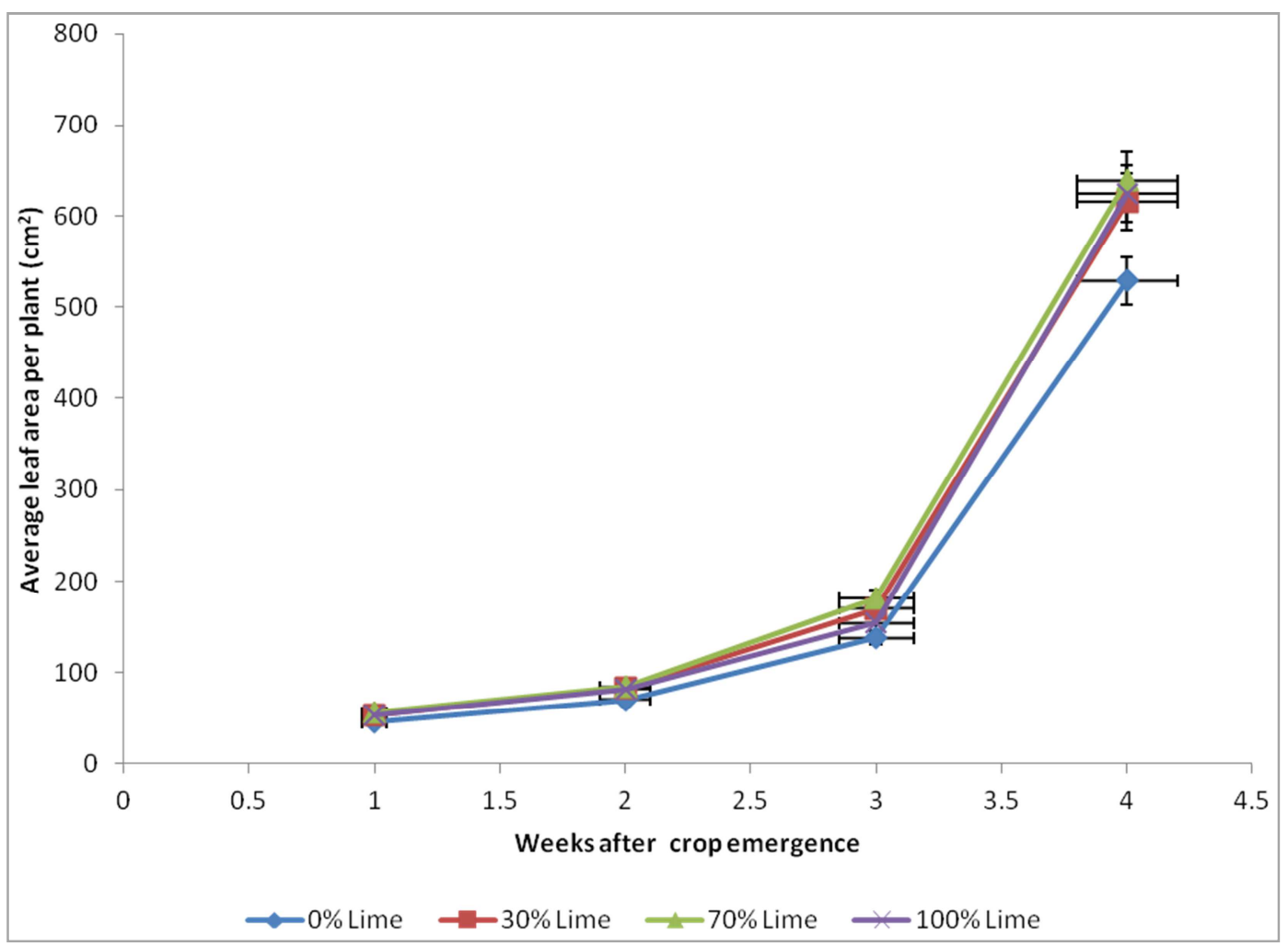

Figure 5. Effects of liming on leaf area index of maize planted in extremely acidic soils (LSD bars inserted).

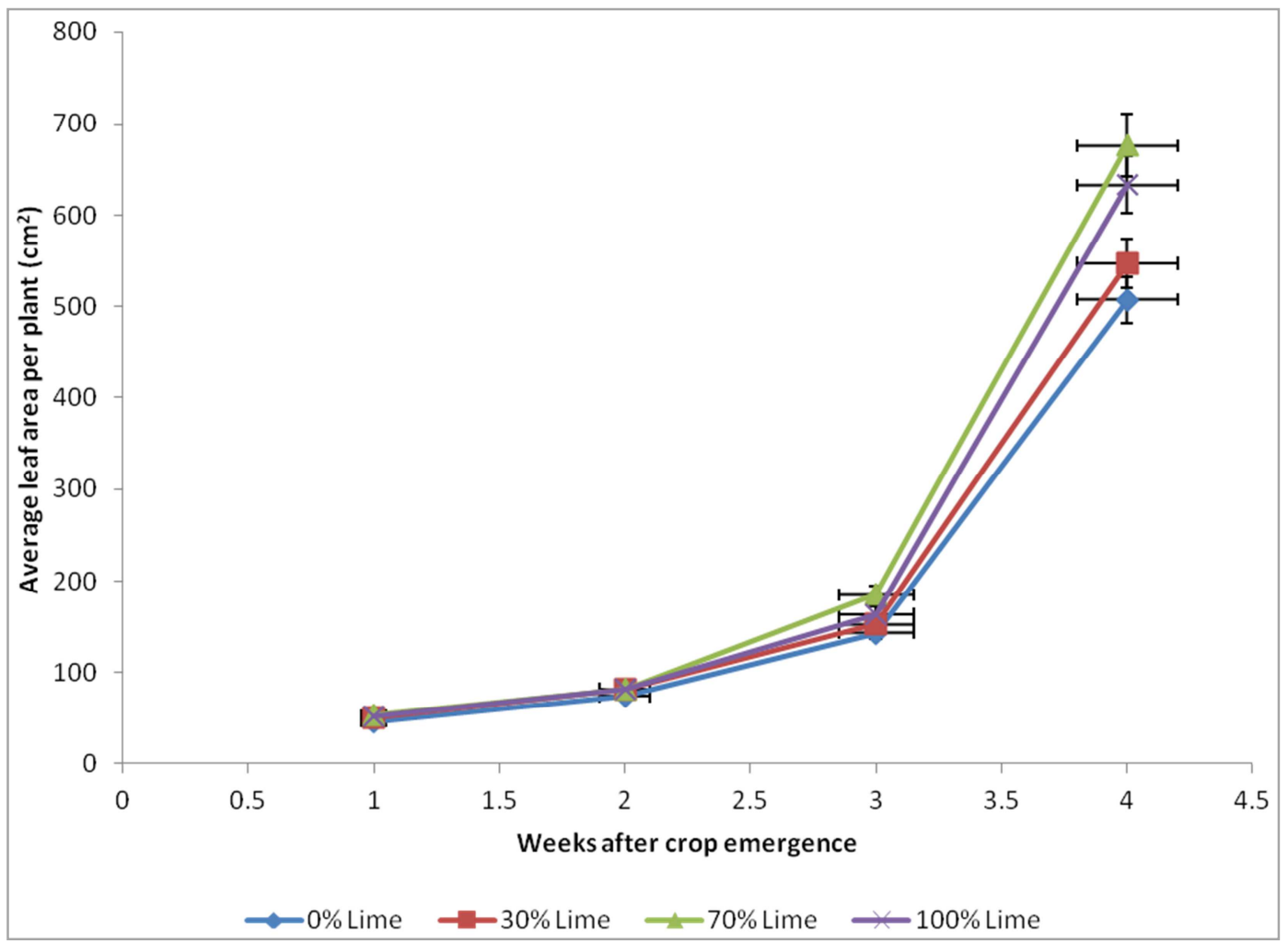

Figure 6. Effects of liming on leaf area index of maize planted in strongly acidic soils (LSD bars inserted).

Phosphorus concentrations in plant tissues 35 days after emergence were observed to increase significantly with lime-Al-P interactions (Table 5). The $\mathrm{P}$ concentration increase was significantly dictated by reduction of $\mathrm{Al}$ concentrations in the soil in the order: $0 \%$ reduction of $\mathrm{Al}^{3+}=30 \%$ reduction of $\mathrm{Al}^{3+}<70 \%$ reduction of $\mathrm{Al}^{3+} \leq 100 \%$ reduction of $\mathrm{Al}^{3+}$ in extremely acidic soils and, $0 \%$ reduction of $\mathrm{Al}^{3+}=30 \%$ reduction of $\mathrm{Al}^{3+}<70 \%$ reduction of $\mathrm{Al}^{3+}=100 \%$ reduction of $\mathrm{Al}^{3+}$ in strongly acidic soils. 
Table 5. Effects of lime-Al-P interactions on P concentration (\%) in maize tissues 35 days after emergence.

\begin{tabular}{|c|c|c|c|c|c|c|c|c|}
\hline \multirow[b]{3}{*}{ Lime to give } & \multicolumn{8}{|c|}{ Phosphorus levels applied (mg $\left.\mathrm{P} \mathrm{kg}^{-1}\right)$} \\
\hline & \multicolumn{4}{|c|}{ Extremely acidic soils } & \multicolumn{4}{|c|}{ Strongly acidic soils } \\
\hline & 0.00 & 0.15 & 0.3 & 0.59 & 0.00 & 0.13 & 0.26 & 0.51 \\
\hline $0 \%$ reduction in $\mathrm{Al}^{3+}$ & $0.17 \mathrm{a}$ & $0.26 \mathrm{a}$ & $0.29 \mathrm{a}$ & $0.31 \mathrm{a}$ & $0.16 \mathrm{a}$ & $0.23 \mathrm{a}$ & $0.28 \mathrm{a}$ & $0.30 \mathrm{a}$ \\
\hline $30 \%$ reduction in $\mathrm{Al}^{3+}$ & $0.20 \mathrm{~b}$ & $0.27 \mathrm{a}$ & $0.30 \mathrm{a}$ & $0.31 \mathrm{a}$ & $0.19 \mathrm{a}$ & $0.23 \mathrm{a}$ & $0.30 \mathrm{a}$ & $0.32 \mathrm{a}$ \\
\hline $70 \%$ reduction in $\mathrm{Al}^{3+}$ & $0.30 \mathrm{c}$ & $0.35 b$ & $0.45 b$ & $0.47 b$ & $0.37 b$ & $0.40 \mathrm{~b}$ & $0.45 b$ & $0.49 \mathrm{~b}$ \\
\hline $100 \%$ reduction in $\mathrm{Al}^{3+}$ & $0.37 \mathrm{~d}$ & $0.43 \mathrm{c}$ & $0.51 \mathrm{c}$ & $0.53 \mathrm{c}$ & $0.34 b$ & $0.41 \mathrm{~b}$ & $0.47 b$ & $0.49 \mathrm{~b}$ \\
\hline$\% \mathrm{CV}$ & 3.50 & 3.50 & 3.50 & 3.50 & 2.90 & 2.90 & 2.90 & 2.90 \\
\hline
\end{tabular}

Values followed by the same letter(s) on the same column are not significantly different at $\mathrm{P} \leq 0.05$.

Lime-Al-P interactions significantly increased maize dry matter yield (Table 6).

It was observed that liming to achieve $100 \%$ reduction in $\mathrm{Al}^{3+}$ significantly $(\mathrm{P} \leq 0.05)$ produced the highest dry matter yields in extremely acidic soils.

Table 6. Effect of lime-Al-P interactions on maize dry matter (tonnes $\left.h a^{-1}\right) 35$ days after emergence.

\begin{tabular}{|c|c|c|c|c|c|c|c|c|}
\hline \multirow[b]{3}{*}{ Lime to give } & \multicolumn{8}{|c|}{ Phosphorus levels applied $\left(\mathrm{mg} \mathrm{P} \mathrm{kg}^{-1}\right)$} \\
\hline & \multicolumn{4}{|c|}{ Extremely acidic soils } & \multicolumn{4}{|c|}{ Strongly acidic soils } \\
\hline & 0 & 0.15 & 0.3 & 0.59 & 0 & 0.13 & 0.26 & 0.51 \\
\hline $0 \%$ reduction in $\mathrm{Al}^{3+}$ & $6.3 \mathrm{a}$ & $29.7 \mathrm{~b}$ & $49.7 \mathrm{c}$ & $39.4 d$ & $11.0 \mathrm{a}$ & $23.0 \mathrm{~b}$ & $43.3 \mathrm{c}$ & $32.2 \mathrm{~b}$ \\
\hline $30 \%$ reduction in $\mathrm{Al}^{3+}$ & $7.4 \mathrm{a}$ & $31.2 \mathrm{~b}$ & $54.1 \mathrm{c}$ & $49.8 \mathrm{c}$ & $13.6 \mathrm{a}$ & $29.1 \mathrm{~b}$ & $48.2 \mathrm{c}$ & $40.5 \mathrm{e}$ \\
\hline $70 \%$ reduction in $\mathrm{Al}^{3+}$ & $15.0 \mathrm{~b}$ & $32.6 \mathrm{~b}$ & $54.7 \mathrm{c}$ & $54.4 \mathrm{c}$ & $14.5 \mathrm{a}$ & $33.4 \mathrm{c}$ & $58.8 \mathrm{~d}$ & $42.3 \mathrm{e}$ \\
\hline $100 \%$ reduction in $\mathrm{Al}^{3+}$ & $21.8 \mathrm{c}$ & $39.1 \mathrm{c}$ & $73.3 \mathrm{~d}$ & $59.0 \mathrm{e}$ & $17.8 \mathrm{a}$ & $41.1 \mathrm{c}$ & $59.3 \mathrm{~d}$ & $44.1 \mathrm{e}$ \\
\hline$\% \mathrm{CV}$ & 2.7 & 2.7 & 2.7 & 2.7 & 4.8 & 4.8 & 4.8 & 4.8 \\
\hline
\end{tabular}

Values followed by the same letter(s) on the same column are not significantly different at $\mathrm{P} \leq 0.05$.

\section{Discussion}

\subsection{Chemical and Physical Characteristic of the Soils}

As per the rating suggested by [31], the soils had low levels of CEC $\left(<15 \mathrm{cmol} \mathrm{kg}^{-1}\right), \mathrm{Ca}\left(<4.0 \mathrm{cmol} \mathrm{kg}^{-1}\right)$ and $\mathrm{P}(<10$ bicarbonate extractable $\mathrm{P}$ ) and high levels of exchangeable aluminium $\left(>2.0 \quad \mathrm{cmolkg}^{-1}\right)$ and $\mathrm{Al}$ saturation $(>20 \%)$ implying that they were of low fertility status. The high levels of $\mathrm{Al}$ and $\mathrm{Al}$ saturation are considered to be toxic to maize plants [26, 32]. According to [9], the soils were strongly to extremely acidic with $\mathrm{pH}$ of 4.48-4.58. Such acid soils with high $\mathrm{Al}^{3+}$ ions, low bases and CEC are characteristic of highly weathered soils, which have lost most of the basic cations through the process of leaching [32]. As a result, their high levels of $\mathrm{Fe}$ and $\mathrm{Al}$ sesquioxides may lead to high $\mathrm{P}$ fixation, resulting in low available $\mathrm{P}[32,33,34,35]$. Additionally, the acidity could be attributed to the mineralogy of the parent materials [35] because most of these soils are developed from non calcareous parent materials such as syenites, phololites, trachytes and nepholites which are acidic in nature [36].

\subsection{The Effect of Lime-Al-P Interactions on Growth of Maize}

The significant $(\mathrm{P} \leq 0.05)$ increase in maize growth after lime application can be attributed to reduced aluminium toxicity which inhibit root growth by reducing cell elongation and cell division hence reduced main axis and lateral root formation [6]. The reduction of Al toxicity by liming occurs through precipitation of soluble and exchangeable $\mathrm{Al}$ as hydroxyl- Al species; the positively charged monomeric
$\mathrm{AlOH}_{2}{ }^{+}$and $\mathrm{Al}(\mathrm{OH})_{2}{ }^{+}$species may polymerize to form both large and small positively charged polynuclear complexes which become sorbed to clay mineral and organic matter surfaces around the root zone [37] hence improved ability of the plants to explore the soil volume for nutrients and water

The significant $(\mathrm{P} \leq 0.05)$ increase of $\mathrm{P}$ concentrations in plant tissues after lime application can be attributed to reduced adsorption-precipitation reaction between $\mathrm{Al}$ and $\mathrm{P}$ at the root surface and in the root free space or ' $\mathrm{P}$ spring effect' of lime $[11,13]$. According to [13], liming may increase plant uptake in soils high in exchangeable and soluble Al by decreasing Al, rather than by increasing $P$ availability per se. This may be due to reduced interference of root cell-plasma membrane by $\mathrm{Al}$, hence improved root growth, allowing a greater volume of soil to be explored $[7,8]$. Once $\mathrm{P}$ is taken up by plants, it plays a great role in energy transfer processes including, photosynthesis which leads to biomass accumulation $[2,38]$. The positive relation between shoot $\mathrm{P}$ and biomass have been reported among sesbania seedlings in Kenyan acid soils [39].

\section{Conclusions}

Lime-Al-P interactions significantly increased P- uptake, maize growth and dry matter yield. Application of lime that leads to $100 \%$ reduction in concentration of $\mathrm{Al}$ ions in the soil (7.4 tones $\mathrm{ha}^{-1}$ for extremely acid soils and 4.5 tones $\mathrm{ha}^{-1}$ for strongly acid soils) significantly reduced the $\mathrm{Al}$ ions in the soils compared to other liming amounts. Combined application of 7.4 tonnes ha ${ }^{-1}$ lime with either $0.59 \mathrm{mg} \mathrm{P} \mathrm{kg}^{-1}$ or $0.3 \mathrm{mg} \mathrm{P} \mathrm{kg}^{-1}$ in extremely acidic soils, and 4.5 tonnes ha ${ }^{-1}$ with either $0.51 \mathrm{mg} \mathrm{P} \mathrm{kg}^{-1}$ or $0.26 \mathrm{mg} \mathrm{P} \mathrm{kg}^{-1}$ in strongly acidic soils did not however, significantly vary in their effect on 
improving plant height, P uptake and dry matter yield. Further studies are therefore, required to ascertain long term, optimal lime-Al-P interactions under field conditions.

\section{Acknowledgment}

The authors express their appreciation to Waruhiu- farmers training centre for provision of research facilities and the Alliance for Green Revolution Africa (AGRA), for funding the research work.

\section{References}

[1] Fageria, N. K. (1994). Soil acidity affects availability of nitrogen, phosphorns, and potassium. Better Crops International. 10:8-9.

[2] Brady, C. N. and Weil, R. R. (2008). The Nature and Properties of Soils, $14^{\text {th }}$ Ed; Pearson Prentice Hall, New Jersey. 975pp.

[3] Parfitt RL (1978) Anion adsorption by soils and soil minerals. Advances in Agronomy 20: 323-359

[4] Luengo, C., Brigante, M., Antelo, J., Avena, M. (2006). Kinetics of phosphate adsorption on goethite: comparing batch adsorption and ATR-IR measurements. Journal of Colloidal Interface Sciences 300: 511-518

[5] Arai, Y. and Sparks, D.L. (2007) Phosphate reaction dynamics in soils and soil minerals: a multiscale approach. Advances in Agronomy 94: 135-179

[6] Foy, C.D. (1988). Plant adaptation to acid, aluminium-toxic soils. Communication in Soil Science and Plant Analysis 19: 959-987.

[7] Kochian, L.V. (1995). Cellular mechanisms of aluminium toxicity and resistance in plants. Annual Review of Plant Physiology and Plant Moleculer Biology 46:237-260.

[8] Haynes, R. J. (1982). Effects of liming on phosphate availability in acid soils. Plant and Soil 68(3):289-308.

[9] Kanyanjua, S. M., Ireri, L., Wambua, S., Nandwa, S. M. (2002) Acid soils in Kenya: Constraints and remedial options. KARI Technical Note, 11:24.

[10] The, C., Calba, H., Zonkeng, C., Ngonkeu, E.L.M., Adetimirin, V.O. (2006). Response of maize grain yield to changes in acid soil characteristics after soil amendment. Plant and Soil 284:45-57.

[11] Fageria KF, Baligar VC, Jones CA. (2010). Growth and mineral nutrition of field crops. $3^{\text {rd }}$ Edition. CRC Press. New York. London. 586Pp.

[12] Haynes, R. J. and Naidu, R. (1998). Influence of lime, fertilizer and manure applications on soil organic matter content and soil physical conditions: a review. Nutrient Cycling in Agro ecosystems 51:123-137.

[13] Bolan, N.S., Adriano, D.C., Curtin, D. (2003). Soil acidification and liming interactions with nutrient and heavy metal transformation and bioavailability. Advances in Agronomy 78: 215-272

[14] Roborage, W.P., and Corey, R.B. (1979). Adsorption of phosphate by hydroxyl aluminium species on a cation exchange resin. Soil Science Society of America Journal 43:481-487.

[15] Sims, J.T. and Ellis, B.G. (1983). Changes in phosphorus adsorption associated with aging of aluminum hydroxide suspensions. Soil Science Society of America Journal 47: 912-916.

[16] Kamprath, E.J. (1970). Exchangeable aluminum as a criterion for liming leached mineral soils. Soil Science Society of America Proceedings 34: 252-254.

[17] Sanchez, P.A. and Uechara, G. (1980). Management considerations for acid soils with high phosphorus fixation capacity. In: The role of phosphorus in Agriculture. (Edited by Khasawneh, F. E., Sample, E. C., Kamprath, E. J.) American Society for Agronomy, Wisconsin. pp.471-514.

[18] Kisinyo, P.O., Opala, P.A., Gudu, S.O., Othieno, C.O., Okalebo, J.R., Palapala, V., Otinga, A.N. (2014a). Recent advances towards understanding and managing Kenyan acid soils for improved crop production. African Journal of Agricultural Research 9(31):2397-2408.

[19] Maier, N.A., McLaughlin, M.J., Heap, M., Butt, M., Smart, M.K. (2002). Effects of current- season application of calcite lime and phosphorus fertilization on soil $\mathrm{pH}$, potato growth, yield, drymatter content, and cadmium concentration. Communications in Soil Science and Plant Analysis 33(13-14): 2145-2165.

[20] Sumner, M.E. (1979). Interpretation of foliar analyses for diagnostic purposes. Agronomy Journal 71:343-348.

[21] Obura, P. A. (2008). Effects of soil properties on bioavailability of aluminium and phosphorus in selected Kenyan and Brazilian soils. Ph. D Thesis, Purdue University, USA. pp. 1-57.

[22] Kisinyo, P.O., Gudu, S.O., Othieno, C.O., Okalebo, J. R., Opala, P.A., Maghanga, J.K., Agalo, J.J., Ngetich, W.K., Kisinyo, J.A., Osiyo, R.J., Nekesa, A.O., Makatiani, E.T., Odee, D.W., Ogola, B.O. (2012). Effects of lime, phosphorus and rhizobia on Sesbania sesban performance in a Western Kenyan acid soil. African Journal of Agricultural Research 7(18):2800-2809.

[23] Muindi, E.M., Mrema J.P., Semu E., Mtakwa P.W., Gachene C.K., Njogu M.K. (2015). Phosphorus adsorption and its relation with soil properties in acid soils of Western Kenya. International Journal of Plant and Soil Science, 4(3):203-211.

[24] Nekesa, A.O. (2007). Effects of Mijingu phosphate rock and agricultural lime in relation to maize, groundnut and soybean yield on acid soils of western Kenya. M.Phil. Thesis. Moi University, Eldoret, Kenya. pp. 1-64.

[25] Kisinyo P.O., Othieno C.O., Gudu S.O., Okalebo, J.R., Opala, P.A., Ng'etich, W.K., Nyambati, R.O., Ouma, E.O., Agalo, J. J., Kebeney, S.J., Too, E.J., Kisinyo. J.A., Opile, W.R. (2014b). Immediate and residual effects of lime and phosphorus fertilizer on soil acidity and maize production in Western Kenya. Experimental Agriculture 50(1):128-143.

[26] Okalebo, J.R., Gathua, K.W., Woomer, P.L. (2002). Laboratory methods of soil analysis: A working manual (2nd ed.). TSBR-CIAT and SACRED Africa, Nairobi, Kenya. 88pp.

[27] Mechlich, A.A., Pinkerton, R. W., Kempton, R. (1962). Mass analysis methods for soil fertility evaluation. Ministry of Agriculture, Nairobi. pp.1-29. 
[28] Fox, R.L. and Kamprath, E.G. (1970). Phosphate sorption isotherms for evaluating the phosphate requirements of soils. Soil Science Society of America Proceedings 34: 902-907.

[29] Cochrane, T. T., Salinas, J. G., Sanchez, P. A. (1980). An equation for liming acid mineral soils to compensate crop aluminium tolerance. Tropical Agriculture (Trinidad) 57: 33-40.

[30] GenStat. (2010). The GenStat Teaching Edition. GenStat Release 7.22 TE, Copyright 2008, VSN International Ltd.

[31] Landon, J.R. (1984). Booker tropical soil manual: A handbook for soil survey and agricultural land evaluation in the tropics and sub tropics. Longman, New York. 450pp.

[32] Landon, J. R. (1991). Booker Tropical Soils Manual: A Handbook for Soil Survey and Agricultural Land Evaluation in the Tropics and Subtropics. John Wiley and Sons, New York. 465pp.

[33] Buresh, R. J., Smithson, P. C., Hellums, D. T. (1997). Building soil phosphorus capital in Africa. In: Replenishing soil fertility in Africa. (Edited by Buresh, P. J. et al.) Soil Science Society of America Special Publication, Madison. pp. 111-149

[34] Sanchez, P.A., Shephard, K.D., Soule, M.J., Place, F.M., Buresh, R.J., Izac, A.N., Mokwunye, A.U., Kwesiga, F.R., Ndiritu, C.G., and Woomer, P.L. (1997). Soil fertility replenishment in Africa: An investment in natural resource capital. In: Replenishing soil fertility in Africa, SSSA Special Publication (Edited by Buresh, R.J., Sanchez, P.A., Calhoun, F.) SSSA, Madison. pp. 1-46.

[35] Van Straaten, P. (2002). Rocks for crops: Agro minerals for sub-Saharan Africa. ICRAF, Nairobi. pp. 25-28.

[36] Sombroek, W. G., Braun, H. M. H., van de Pouw. (1982). Exploratory soil map and agro-climatic zone map of Kenya. Scale 1:1000, 000. Exploratory soil survey report No. E1. Kenya Soil Survey, Nairobi. pp. 1-78.

[37] Stol R.J., Van Helden A.K., de Bruyn P.L. (1976) Hydrolysis precipitation studies of aluminium (III) solutions. 2. A kinetic study and model. Journal of Colloid Interface Sci ence57: 115131

[38] Xie, P., Niu, J., Gan, Y., Gao, Y., Li, A. (2015). Optimizing phosphorus fertilization promotes dry matter accumulation and $\mathrm{P}$ remobilization in oilseed flax. Crop Science 54(4):1729-1736.

[39] Gudu, S. O., Kisinyo, P. O., Makatiani, E. T., Odee, D.W., Esegu, J. F. O., Chamshama, S. A. O., Othieno, C. O., Okalebo, J. R., Osiyo, R. J. and Owuoche, J.O. (2009). Screening of Sesbania for tolerance to aluminum toxicity and symbiotic effectiveness with acid tolerant rhizobia strains in Western Kenya acid soils. Experimental Agriculture 45:417-427. 